\title{
Managing Supply Chain Complexity in a Tea Manufacturing Company
}

\author{
I Nyoman Pujawan* \\ Department of Industrial Engineering, \\ Sepuluh Nopember Institute of Technology, Kampus ITS Sukolilo, \\ Surabaya 60111 Indonesia \\ E-mail: pujawan@ie.its.ac.id \\ Mahendrawathi Er \\ Department of Information Systems, Faculty of Information Technology, \\ Sepuluh Nopember Institute of Technology, Kampus ITS Sukolilo, \\ Surabaya 60111 Indonesia \\ E-mail:mahendra_w@its-sby.edu
}

\begin{abstract}
In this case we present issues facing supply chain management in a tea manufacturing company. The company manages two types of products, ready-to-drink jasmine tea and ready-to-drink fruity tea, each having different complexity issues in their supply chain management processes. The case explains characteristics of the products, the supply chain structures, and the nature of demand. The case is expected to facilitate discussions of various supply chain concepts such as the bullwhip effect, supply chain coordination, and vertical integration versus outsourcing.
\end{abstract}

Keywords: supply chain complexity, information distortion, case study, tea manufacturing

\section{The First Meeting}

It was Friday, June 27, 2008. The coordination meeting between the marketing, distribution, and production departments was taking place. "Some stores have been out of stock of some types of Fteh in the last few days," the distribution manager of Tehindo, a producer and distributor of tea products in Indonesia, informed the attendees. Fteh is their brand name for ready-to-drink tea with a fruity flavor.

"We have too many product variants of fruity tea. Such a significant shortage has never happened to our main product, Goteh. Why don't we focus on Goteh? Its sales volume is high and demand fluctuation is low," the operations manager added.

The marketing manager responded after a brief of silence, "It is indeed true what the operations manager mentioned. But, if we want to enter wider market segments, it is a must for us to keep innovative products with more variants in the market. In the future, there is no doubt that innovative products like Fteh with various flavors will hold a strong market segment. Their contribution to revenue is increasing over time."

\footnotetext{
* Corresponding Author

This case was prepared solely to provide material for classroom discussion. The authors do not intend to illustrate either effective or ineffective handling of a managerial situation. The authors have disguised some names and other identifying information to protect confidentiality. The views presented here are those of the case authors and do not necessarily reflect the views of Operations and Supply Chain Management: An International Journal. Copyright () 2009 by Operations and Supply Chain Management: An International Journal and the authors. If you are an instructor and wish to adopt the case for your class, please contact the corresponding author or the special issue editor to obtain the teaching notes.
} 
"But too many variants of Fteh increase the difficulties in production and distribution activities. Our performance looks bad because we often experience out of stock situations for certain variants, but an excess of inventory for other Fteh products," the distribution manager continued.

The marketing manager insisted that the increasing number of new variants of Fteh has enabled the company to hold a strong segment of teenagers. The classic Goteh did not really embrace the teenager segment of the market.

\section{Company Background}

Tehindo has a long history in the tea business. The company began as a small home business in Indonesia in the 1940s. The owner started the tea business in Central Java, but then moved to Jakarta in an attempt to capture larger markets after some 25 years. The company opened its first factory in the mid-1970s in Jakarta, producing ready-to-drink bottles of tea. The opening of the factory created a significant increase in sales, reflecting a healthy market for tea products.

\section{Products}

Today, Tehindo produces three types of tea products. The first is called Goteh, a jasmine tea mostly packaged in glass bottles. A small percentage of this tea is also packaged in tetra packs (a small carton box) or tetra wedge (a small carton in the shape of triangular pyramid). The bottled jasmine tea is very popular in Indonesia and contributes the majority of revenue to the company. The product is consumed by all market segments. The second product type is called Fteh, a tea with a fruity flavor, packaged either in glass bottles, tetra packs, or cans. Fruity tea is more directed toward teenagers and the distribution of products is through modern retail chains such as Sogo, Giant, Carrefour, Alfa, Superindo, Torseba Yogya, and Indomaret. The third product category is Cteh, a dried, chopped, and ready-to-boil tea leaf, normally packaged in tea bags.

Among the three classifications, only the first and the second types are discussed in this case. Unlike Goteh, which has only very limited product variants, as shown in Table 1, Fteh has a large
Table 1. Product variants for Goteh and Fteh

\begin{tabular}{|l|l|c|c|}
\hline \multicolumn{1}{|c|}{ Product Group } & Packaging & Size (ml) & $\begin{array}{c}\text { Number of } \\
\text { flavors }\end{array}$ \\
\hline Goteh (Ready-to-drink & Glass bottle & 220 & 1 \\
jasmine tea) & Tetra pack & 200 & 1 \\
& Tetra pack & 250 & 1 \\
Fteh (Ready-to-drink & Glass bottle & 235 & 8 \\
fruity tea) & Tetra wedge & 200 & 9 \\
& Can & 318 & 9 \\
& Plastic bottle PET & 500 & 5 \\
\hline
\end{tabular}

number of variants based on the product flavors. Currently, the company offers various flavors of Fteh including guava, strawberry, lemon, apple, and black currant.

In the soft drink industry in general, there are two types of products according to their packaging. The first is called return glass bottle (RGB), where the empty packages are returned to the factory and used to produce new products. The second category is one-way product (OWP), where the packages will not be returned to the factory but will be disposed of after the products have been consumed. In Tehindo, only the glass bottles are classified as RGB, while the others are classified as OWP.

Managing RGB products is certainly more complicated than OWP. One of the challenges would be to ensure a smooth flow of the products downstream as well as the empty bottles upstream. High inventory levels at some supply chain players for various reasons (including forward buying and forecast inaccuracy) would result in shortages of empty bottles at the factories for a certain period of time. Tehindo has a policy of announcing any price increase two weeks prior to the increase date. This is simply to please the wholesalers and retailers as they usually feel uncomfortable with a sudden price change (note that some other soft drink companies in Indonesia do not give wholesalers and retailers the privilege of knowing price increases well in advance, as this company does). To avoid massive forward buying, the company requires the retailers and wholesalers to exchange empty bottles for full bottles, if they order within the two week period from when the price increase is first announced until the date of the actual increase. Obviously, this is not possible for the OWP. 


\section{Supply Chain Network}

Currently, Tehindo has two main interrelated businesses: one is in manufacturing and the other is in the distribution of tea products. The manufacturing processes are based in ten manufacturing plants whose locations are spread across three islands in Indonesia: Sumatera, Java, and Bali. One of the factories (located in West Java) is dedicated to producing OWP and supplies all the distribution centers. Other factories produce both RGB and OWP products. The supply policies are generally based on geographical proximity. For example, two factories in Sumatera supply the whole market area on Sumatera island, while the factory in Bali supplies Bali and the Nusa Tenggara market area.

To produce ready-to-drink tea, only a couple of types of materials are needed. The materials for producing jasmine tea are tea leaves, water, and sugar. For fruity tea, the fruit extract and other additional materials are also needed. The production process is quite simple. The liquid sugar, tea extract, and fruit extract as well as other materials are mixed, sterilized, and then packaged.

A vertical integration model is still very much practiced in this company. The tea leaves are supplied by a company within the Tehindo corporate organization. It has a total of over 1500 hectares of tea plantations in different areas in West Java.
Downstream, the products are distributed through 11 regional sales centers located in Sumatera, Java, Bali, Kalimantan, and Sulawesi. Each regional sales center has a number of sales offices and warehouses. Overall, there are about 150 sales offices all over Indonesia. In East Java alone, for example, there are 17 sales offices. East Java is one of the major market areas for Tehindo.

There are four different distribution channel configurations, as depicted in Figure 1. From the figure, it is evident that some products are shipped directly to consumers. This happens when there is a large order from an individual or an organization for such events as parties or gatherings. The other possibility is to deliver the products from the sales center to retailers who will then sell the products to the end customers. The retailers here could be a supermarket, a shop, a restaurant, or other parties selling the products to the end customers. The other model is to deliver the products through the wholesalers and retailers. Finally, the company has recently worked with a third-party distributor to manage the distribution of the products. However, this outsourcing practice is only for OWP products that are delivered through traditional rather than modern retail chains.

It is interesting to note that the company does not use a third-party distributor to handle the distribution of OWP products to modern retail

Figure 2. Four types of distribution channels for tea products produced by Tehindo
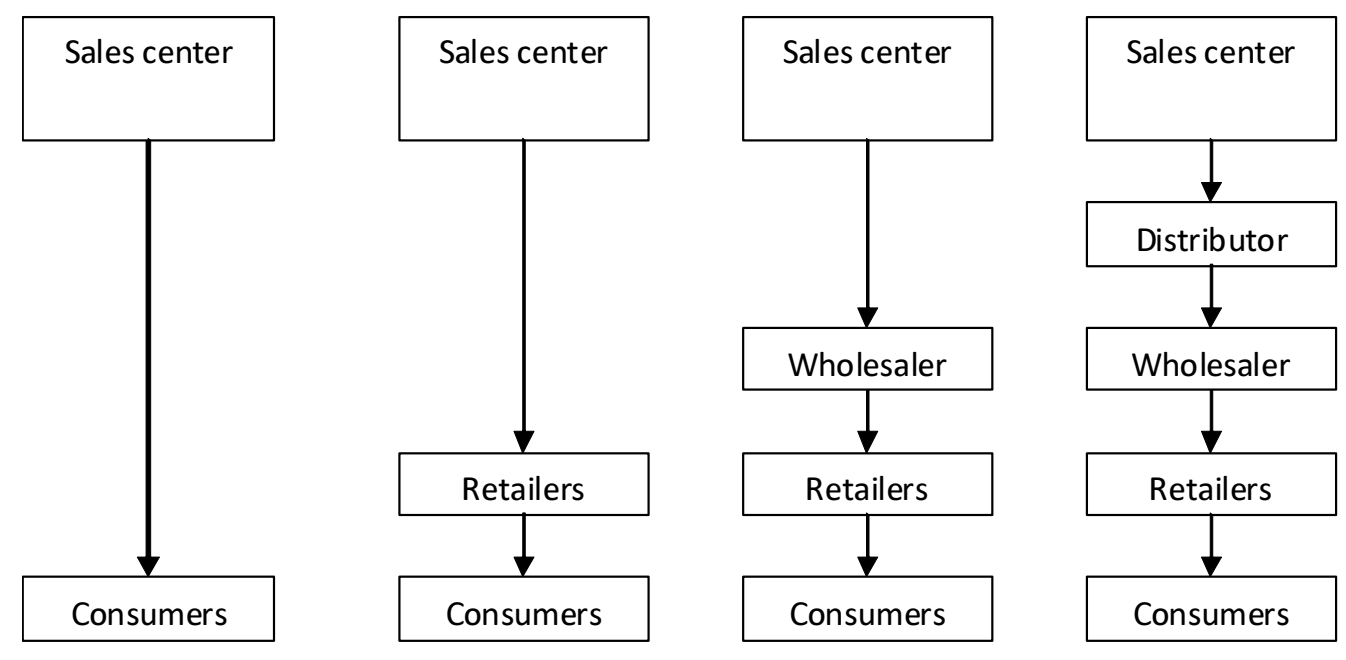
chains. There are two reasons behind this policy. First, the margin is relatively tiny for OWP products sold through modern retail outlets, making it financially infeasible to use third-party distributors. Second, modern retail outlets often initiate various marketing schemes such as promotions and discounts, making it difficult for third-party distributors to have customized deals.

\section{Market Demand}

Orders coming from wholesalers and retailers are affected by a number of factors. First, price increases are set by the company. As mentioned above, the company announces a price increase two weeks prior to the actual increase date. This enables the wholesalers and retailers to carry out forward buying. Orders tend to be high within two weeks prior to the price increase, and then drop for some time after the increase. Second, orders tend to be quite high in anticipation of demand increases due to such events as religious celebration days and New Years.

In reality, the price increases set by the company do not really affect final consumption. Increased orders are not because of an increased demand from the consumers, but only to respond to the price increases from the factory. Thus, the increase in orders from wholesalers and retailers only happens temporarily and then will drop to a level below average for some time after a price increase. As a consequence, the retailers and wholesalers hold larger inventories temporarily. For New Years and other events, there is normally a real increase in demand from the consumers.

Unlike traditional market outlets such as small food sellers and groceries, promotional activity is a norm for modern retail chains. Retailers like Carrefour, Giant, and Alfa often launch promotional events (such as buy 2 get 3, and prize drawings). Obviously, such promotional activities can increase sales of tea products to the consumers. However, the increase in demand would result in shortages if any member of the supply chain is not ready to respond.

In terms of sales volume, Goteh by far outperforms Fteh. As mentioned above, Goteh is mainly sold through the traditional market, while Fteh is mainly sold through modern retail chains.
Table 2. Comparison of Fteh sales in the East Java region through modern market outlets vs. total sales for 2006

\begin{tabular}{|c|c|c|}
\hline Fteh Flavors & $\begin{array}{c}\text { Annual sales through } \\
\text { modern markets }\end{array}$ & $\begin{array}{c}\text { Annual sales total } \\
\text { for East Java }\end{array}$ \\
\hline APP & 17,512 & 41,222 \\
LMN & 9,994 & 18,900 \\
STR & 11,525 & 30,085 \\
GVA & 15,404 & 35,425 \\
ORG & 8,764 & 26,125 \\
BLC & 13,612 & 33,852 \\
FSN & 8,915 & 37,405 \\
BLS & 7,007 & 35,240 \\
XTR & 10,685 & 41,436 \\
\hline
\end{tabular}

Table 2 shows comparisons of sales of Fteh through the modern retailers and the total for East Java. It is obvious from the table that the sales of Fteh through modern market outlets account for a very large percentage of sales. As a consequence, the dynamic of orders to sales centers and factories is very much affected by promotional activities conducted by these modern outlets.

\section{The Second Meeting}

On August 15, 2008, the managers were engaged in another meeting. The issue of product variety once again became a hot topic. The marketing manager showed sales data of the two types of products, Goteh and Fteh. A newly appointed supply chain manager attended the meeting. There was a discussion on whether or not the company should reduce the product variants of the fruity tea.

\section{Discussion Questions}

1. Make a diagram showing the supply chain configuration of Tehindo as well as the flow of products and information within the supply chain.

2. Compare the bottled Goteh and Fteh in terms of challenges in managing their supply chain processes.

3. Discuss the causes of temporary demand (and order) increases in this supply chain. 
4. If you were the supply chain manager of this company, what would be your suggestions in the second meeting?

5. How does information distortion happen in this supply chain and what would be your suggestions to reduce it?

6. Discuss the advantages and disadvantages of vertical integration and outsourcing for Tehindo.

\section{Acknowledgments}

The authors would like to thank two anonymous reviewers for their excellent comments and to Professor Joel Wisner, the editor of the special issue, for handling the review process very well. The research leading to this publication was funded by Directorate General of Higher Education, Department of National Education, the Government of Indonesia under grant No. 017/HIKOM/DP2M/ 2008.

Nyoman Pujawan is a Professor of Supply Chain Engineering at the Department of Industrial Engineering, Sepuluh Nopember Institute of Technology (ITS), Surabaya, Indonesia. He received a bachelor degree in Industrial Engineering from ITS, Master of Engineering in Industrial Engineering from Asian Institute of Technology (AIT) Bangkok, Thailand, and PhD in Management Science from Lancaster University, UK. He had been a lecturer in Manchester Business School, The University of Manchester, UK. His papers have been published or accepted for publication in the International Journal of Production Economics, European Journal of Operational Research, Production Planning and Control, Business Process Management Journal, among other international journals. He is also the Editor-in-Chief of Operations and Supply Chain Management: An International Journal. His e-mail address is <pujawan@ie.its.ac.id>

Mahendrawathi Er is a Lecturer in the Department of Information Systems, Faculty of Information Technology, Sepuluh Nopember Institute of Technology, Indonesia. She received a Doctoral Degree in Manufacturing Engineering and Operations Management from Nottingham University, United Kingdom in 2004. Her teaching and research interests include supply chain management, international operation, product variety management, modeling and simulation. She has published papers in international journals and conferences. Her email address is <mahendra_w@its-sby.edu> 